\title{
PENGGUNAAN Trichoderma Koningii PADA PERKECAMBAHAN SIRSAK (Annona muricata linn)
}

\author{
Erida Derita Dalame \\ Bertje Richard Albert Sumayku \\ Jeany Polii-Mandang
}

\begin{abstract}
Naskah diterima melalui Website Jurnal Ilmiah agrisosioekonomi@unsrat.ac.id : Kamis, 21 November 2019
Disetujui diterbitkan

: Kamis, 28 November 2019
\end{abstract}

\begin{abstract}
This study aims to determine the dose of Trichoderma koningii which can induce soursop germination; know the best soaking time that can affect the induction of soursop germination; to know the interaction between soaking time and Trichoderma koningii dose on soursop germination. This research was conducted in April - June 2019 at the Green House of Plant Sciences, Faculty of Agriculture, Sam Ratulangi University, Manado. The material used in this study was soursop seed obtained from Lota Village, Pineleng Tomohon Subdistrict, Trichoderma koningii with 106 solids obtained from the North Sulawesi Province Plant Protection Center Collection, Aquadest, 70\% Alcohol, $80 \%$ Acetone, sand already sifter and sterilized. This research was arranged in factorial with a Completely Randomized Design (CRD) consisting of two factors, namely 5 treatments of Trichoderma koningii dose and 4 immersion treatments repeated three times $(3 x)$ so that a total of 60 treatment units. Each treatment unit uses 10 seeds. The results of this study indicated that the dose of Trichoderma koninggi $200 \mathrm{~g}$ without soaking can increase the germination power by $86.67 \%$ and the vigor index by $32.96 \%$; Immersion with Koninggi Trichoderma suspension has not been able to induce soursop seed germination rate; The interaction between Trichoderma koningii dose and soaking time did not affect the speed of soursop seed germination. ${ }^{*}$ eprm*
\end{abstract}

Keywords: Trichoderma koningii, germination capacity, vigor index, and germination speed.

Penelitian ini bertujuan untuk mengetahui dosis Trichoderma koningii yang dapat menginduksi perkecambahan sirsak; mengetahui waktu perendaman terbaik yang dapat mempengaruhi induksi perkecambahan sirsak; mengetahui interaksi lama perendaman dengan dosis Trichoderma koningii terhadap perkecambahan sirsak. Penelitian ini dilakukan pada Bulan April - Juni 2019 bertempat di Green House Ilmu Tanaman Fakultas Pertanian Universitas Sam Ratulangi Manado. Bahan yang digunakan dalam penelitian ini adalah benih sirsak yang di peroleh dari Desa Lota, Kecamatan Pineleng Tomohon, Trichoderma koningii dengan padatan 106 di peroleh dari Koleksi Balai Perlindungan Tanaman Propinsi Sulawesi Utara, Aquadest, Alkohol 70\%, aceton 80\%, pasir yang sudah di ayak dan di sterilkan. Penelitian ini disusun secara factorial dengan Rancangan Acak Lengkap (RAL) yang terdiri dua factor yaitu 5 perlakuan dosis Trichoderma koningii dan 4 perlakuan perendaman di ulangan tiga kali (3x) sehingga total 60 unit perlakuan. Setiap unit perlakuan menggunakan 10 benih. Hasil penelitian ini menunjukkan bahwa dosis Trichoderma koninggi $200 \mathrm{~g}$ tanpa rendam mampu meningkatkan daya kecambah sebesar 86,67 \% dan indeks vigor sebesar 32,964 \%; Perendaman dengan suspesi Trichoderma koninggi belum dapat menginduksi kecepatan perkecambahan benih sirsak; Interaksi antara dosis Trichoderma koningii dan lama perendaman tidak berpengaruh terhadap kecepatan perkecambahan benih sirsak. ${ }^{*}$ eprm*

Kata kunci : Trichoderma koningii, daya kecambah, indeks vigor, dan kecepatan kecambah. 


\section{PENDAHULUAN}

\section{Latar Belakang}

Pengembangan sirsak tidak terlepas dari ketersediaan bibit dalam jumlah yang banyak dan waktu yang tepat. Tanaman sirsak dapat diperbanyak melalui biji dan dapat tumbuh baik pada tanah liat berpasir. Perkecambahan benih sirsak terhitung lambat. Hal ini karena benih tersebut mempunyai kulit biji yang keras sehingga sulit ditembus air. Oleh karena itu masa dormansi biji sirsak juga cukup lama yaitu bervariasi antara 1-3 bulan (Badrie dan Schauss, 2009). Purnomosidhi dkk (2013) menyatakan bahwa benih bisa disimpan 1-2 minggu, kecambah dan tunas akan tumbuh 2-3 minggu setelah semai. Hasil penelitian Amalia (2016), dengan menggunakan air hujan waktu yang terbaik munculnya kecambah benih sirsak terjadi pada hari ke-20 dengan konsentrasi $200 \mathrm{ml}$ air hujan/5 benih sirsak.

Guna memperoleh ketersediaan bibit yang dalam jumlah banyak, pertumbuhan seragam dan sehat, di perluhkan suatu metode dalam memacuh perkecambahan benih sirsak. Untuk memacuh perkecambahan benih sirsak penulis mencoba meneliti dengan menggunakan Trichoderma koningii. Salah satu agens hayati yang dapat meningkatkan proses perkecambahan benih yaitu Trichoderma. Beberapa spesies Trichoderma terbukti juga dapat menghasilkan zat pengatur tumbuh seperti indolacetid acid (IAA), spesies Trichoderma akan mengkoloni dan tumbuh berasosiasi dengan perakaran tanaman (Harman et $a l, 2004)$. Seperti hasil penelitian sebelumnya tentang efek Trichoderma spp. pada perbaikan perkecambahan biji kedelai (Tancic et al, 2013), mustard (Lalitha et al, 2012), jagung dan kacangkacangan (Okoth et al. 2011) dan cabai (Asaduzzaman et al, 2010).

Trichoderma merupakan kapang atau sejenis jamur yang mampu menghasilkan enzim selulotik. Enzim selulotik merupakan enzim yang mampu mendegradasi selulosa yang terletak pada dinding sel tumbuhan. Dinding sel tanaman tersusun dari selulosa, sekitar $35-50 \%$ selulosa dari berat kering tanaman terkandung pada dinding sel tanaman tingkat tinggi (Lynd et al, 2002).

Selain itu menurut Delgado-Sanchez et al (2010) bahwa Jamur tumbuh di testa benih mengikis dan meretakan kulit yang keras, dengan demikian berpotensi dapat mengurangi resistensi mekanik untuk perkecambahan benih dengan dormansi fisiologi. Genus Trichoderma merupakan komponen utama mycoflora dalam berbagai jenis ekosistem tanah, seperti ladang pertanian, padang rumput, hutan, rawa garam dan gurun, di semua zona iklim (Smith, 1995 and Harman, 2000). Beberapa jenis digunakan sebagai agen untuk meningkatkan kecambah benih dan efisiensi penggunaan nutrisi, pecahnya dormansi benih, serta sumber transgen dan herbisida hayati, diketahui dapat meningkatkan pertumbuhan tanaman melalui produksi fitohormon dan metabolit sekunder (Harman et al. 2004, Shoresh et al, 2010). Baru-baru ini di temukan Trichoderma yang menghasilkan molekul mirip sitokinin, misalnya zeatyn dan gibberellin GA3 atau yang berhubungan dengan GA3 (Osiewacz,2002). Aplikasi Trichoderma dapat meningkatkan persentase perkecambahan dan pertumbuhan bibit (Kaveh et al, 2011).

Hasil penelitian Zheng dan Shetty (2000) melaporkan bahwa Trichoderma spp. menginduksi produksi senyawa fenolik selama perkecambahan biji dan senyawa fenolik yang dihasilkan oleh Trichoderma spp. menyebabkan peningkatan indeks vigor benih. Lebih lanjut Cai et al (2013) menyatakan bahwa metabolit sekunder yaitu harzianolide diproduksi oleh Trichoderma spp. dapat mempengaruhi tahap awal perkembangan tanaman melalui peningkatan panjang akar. Menurut Ali et al (2014) persentase perkecambahan biji kacang buncis meningkat dengan aplikasi Trichoderma, stimulator perkecambahan biji yang paling aktif adalah Trichoderma harzianum, Trichoderma viride dan Trichoderma koningii. Dengan panjang akar semai maksimum diperoleh pada Trichoderma harzianum diikuti oleh Trichoderma viride dan Trichoderma Koningii juga di peroleh berat bibit segar dan kering tertinggi pada Trichoderma viride dan Trichoderma Koningii.

Selanjutnya menurut Delgado-Sánchez et al (2010) menyatakan bahwa biji O. Leucotricha yang diinokulasi dengan empat spesies jamur (Penicillium chrysogenum, Phoma sp, Trichoderma harzianum, Trichoderma koningii) memiliki perkecambahan yang lebih tinggi dari pada kontrol. Sejalan dengan Mukhtar et al (2012) 
mengatakan perlakukan biji dengan Trichoderma harzianum, Trichoderma viridi dan Trichoderma koningii juga menunjukkan persentase perkecambahan yang tinggi dibandingkan dengan kontrol. Menurut Windham et al (1986) penambahan Trichoderma ke biji meningkatkan presentase perkecambahan. Hasil ini menyimpulkan bahwa Trichoderma spp. menghasilkan zat pengatur pertumbuhan yang mendorong perkecambahan biji dan peningkatan biomassa (Baker et al, 1984; Windham et al, 1986).

Hasil penelitian Cutler et al (1989), Trichoderma koningii mengandung koningin A. Koningin A merupakan produk alami dengan struktur yang khas dan dapat memacuh pertumbuhan hipokotil tanaman (Sumayku dkk, 2017). Respons dari aplikasi Trichoderma harzianum adalah dengan meningkatnya persentase perkecambahan, tinggi tanaman, dan bobot kering serta waktu perkecambahan yang lebih singkat pada tanaman sayuran (Baker et al, 1984; Chang et al, 1986, Paulitz et al, 1986) dan cepat berbunga serta meningkatkan dompolan bunga pada Vinca minor L, dan petunia (Petunia hybrid Vilm) (Baker et al, 1984; Chang et al, 1986).

Dari empat macam auxin yaitu giberelin, sitokinin, asam absisat dan etilen, diduga etilen merupakan hormon yang dihasilkan oleh jamur Trichoderma spp. yang dapat memacu pembungaan pada bibit vanili (Sudanta, 2010). Lebih lanjut Salisbury dan Ross (1995) mengungkapkan bahwa beberapa jenis jamur yang hidup di tanah dapat menghasilkan etilen. Diduga etilen yang dilepaskan oleh jamur tersebut membantu mendorong perkecambahan biji, mengendalikan pertumbuhan kecambah, memperlambat serangan organisme patogen tular tanah, dan memacu pembentukan bunga.

Penelitian Wijayanti dan Rahmawati (2017) pada benih oyong dengan lama perendaman Trichoderma s $p$. memberikan hasil pengaruh nyata pada parameter Indeks Dormansi (ID) dan pengaruh sangat nyata pada Parameter Kecepatan Tumbuh. Benih Oyong yang yang direndam menggunakan larutan Trichoderma sp. selama 2 hari tanpa disimpan memiliki Kecepatan Tumbuh diatas 17\%/ etmal, yaitu $17,65 \%$ / etmal.
Hasil peneltian Rahayu (2016), menyatakan bahwa ternyata disamping menekan populasi nematoda, aplikasi $T$. harzianum dan $T$. koningii juga dapat merangsang pertumbuhan bibit kopi. Menurut Nurahmi (2012) Trichoderma spp tidak memberikan respons yang positif terhadap perkecambahan benih tomat dan kedelai namun masih dapat di tolerir pada perkecambahan kakao. Murniaty (1995) menyatakan bahwa Trichoderma koningii merusak serat kulit benih. Derajat kerusakan Trichoderma koningii selama 3-4 minggu sama dengan kerusakan kulit benih yang mampu berkecambah secara alami selama 5-6 bulan.

Semua hasil-hasil penelitian tentang Trichoderma spp yang dapat meningkatkan perkecambahan pada benih, namun sangat sedikit informasi yang tersedia sehubungan dengan peningkatan perkecambahan dan kekuatan benih oleh Trichoderma spp. pada benih-benih yang berkulit keras dan tebal oleh karena itu penulis tertarik untuk melakukan penelitian dengan menggunakan Trichoderma Koningii untuk meningkatkan perkecambahan pada benih yang keras seperti sirsak. Salah manfaat dari Trichoderma Koningii yaitu meningkatkan pertumbuhan bibit dan mengeluarkan hormon perkecambahan benih.

\section{Rumusan Masalah}

1. Berapa dosis Trichoderma koningii yang dapat menginduksi perkecambahan sirsak

2. Apakah waktu perendaman mempengaruhi induksi perkecambahan

3. Apakah ada interaksi antara perendaman dengan dosis Trichoderma koningii Terhadap perkecambahan sirsak

\section{Tujuan Penelitian}

Penelitian ini bertujuan untuk

1. Mengetahui dosis Trichoderma koningii yang dapat menginduksi perkecambahan sirsak

2. Mengetahui waktu perendaman terbaik yang dapat mempengaruhi induksi perkecambahan sirsak

3. Mengetahui interaksi perendaman dengan dosis Trichoderma koningii terhadap perkecambahan sirsak.

\section{Manfaat Penelitian}

Manfaat penelitian adalah sebagai sumber informasi ilmiah bagi masyarakat tentang penggunaan Trichoderma koningii pada perkecambahan benih sirsak. 


\section{METODE PENELITIAN}

\section{Waktu dan Tempat Penelitian}

Penelitian Ini Dilakukan Pada Bulan April - Juni Tahun 2019 bertempat Di Green House Ilmu Tanaman Fakultas Pertanian Universitas Sam Ratulangi Manado.

\section{Bahan dan Alat}

Bahan yang digunakan dalam penelitian ini adalah benih sirsak yang di peroleh dari Desa Lota Kecamatan Pineleng Tomohon, Trichoderma koningii dengan padatan 106 di peroleh dari Koleksi Balai Perlindungan Tanaman Propinsi Sulawesi Utara, Aquadest, Alkohol 70\%, aceton $80 \%$, pasir yang sudah di ayak dan di sterilkan. Dan alat yang digunakan adalah polybag, oven, timbangan analitik, mistar, centrifus, gelas ukur, spektrofotometer, label, gelas kimia, mortal, kuvet, timbangan analitik, alat tulis, tabung reaksi, lumpang, wadah perendaman.

\section{Metode Penelitian}

Penelitian ini disusun secara factorial dengan Rancangan Acak Lengkap (RAL) yang terdiri dua factor yaitu 5 perlakuan dosis Trichoderma koningii dan 4 perlakuan perendaman di ulangan tiga kali $(3 \mathrm{x})$ sehingga total 60 unit perlakuan. Setiap unit perlakuan menggunakan 10 benih. Dapat dilihat pada Tabel 1. 1. Faktor pertama dosis Trichoderma Koningii Tanpa Trichoderma koningii $(\mathrm{To})=$ Kontrol Trichoderma koningii $1\left(\mathrm{~T}_{50}\right)=50 \mathrm{gr} / \mathrm{Liter} / 40$ benih Trichoderma koningii $2\left(\mathrm{~T}_{100}\right)=100 \mathrm{gr} / \mathrm{Liter} / 40$ benih Trichoderma koningii $3\left(\mathrm{~T}_{150}\right)=150 \mathrm{gr} / \mathrm{Liter} / 40$ benih Trichoderma koningii $4\left(\mathrm{~T}_{200}\right)=200 \mathrm{gr} / \mathrm{Liter} / 40$ benih 2. Faktor kedua waktu perendaman

Tanpa rendam $(\mathrm{R} 0)=$ control

Rendam 1(R6) $=6$ jam

Rendam 2(R12) = 12 jam

Rendam 3(R18) = 18 jam

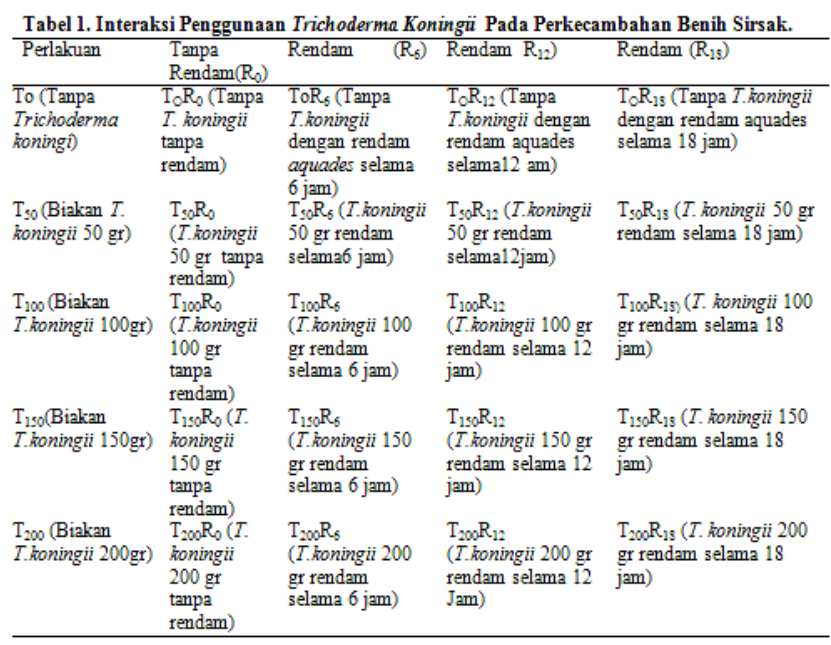

\section{Pelaksanaan Penelitian}

1. Persiapan Benih

a. Benih yang di gunakan berasal dari buah sirsak yang diperoleh dari Desa Lota Kecamatan Pineleng Tomohon.

b. Buah di peram hingga masak, setelah masak buah di kupas

c. Di pilih benih pada tengah buah

d. Benih di masukan kedalam air

e. Biji yang tenggelam di gunakan sebagai benih di seleksi lagi berdasarkan ukuran dan warna yang seragam

f. Sebelum benih di gunakan, disterilkan terlebih dahulu dengnan alkohol $70 \%$

g. Lalu di bilas dengan aquades sampai bensih

2. Persiapan Trichoderma koningii

a. Trichoderma koningii yang di gunakan dalam penelitian ini di peroleh dari koleksi Balai Perlindungan Tanaman Propinsi Sulut

b. Trichoderma koningii di timbang sesuai dengan kebutuhan perlakuan, pada perlakuan perendaman biakan Trichoderma koningii di larutkan dengan air mineral dengan perbandingan 1 liter/40 benih kemudian di goncang sekitar 1 menit, benih di rendam sesuai dengan durasi waktu perlakuan. Menurut Wirawan (2018) perendaman benih padi dengan suspensi tiga jenis Trichoderma spp. dengan kerapatan $10^{3} \mathrm{cfu} / \mathrm{ml}$ air selama 6 jam, hasil penelitian menunjukan bahwa aplikasi Trichoderma sp. mengurangi keparahan penyakit hawar daun bakteri (HDB) yang disebabkan oleh Xanthomonas oryzae pv. oryzae (Xoo) dan Trichoderma sp. juga dapat meningkatkan panjang akar dan tinggi tanaman padi. Hasil penelitian Polhaupessy (2011) dengan konsentrasi GA dan waktu perendaman yang berbeda, perlakuan 15 ppm GA dengan perendaman 12 jam yaitu 100\%, meningkatkan tinggi tanaman 16,12 $\mathrm{cm}$, dan panjang akar 12,99 $\mathrm{cm}$. Perendaman benih dengan Trichoderma spp sebelum tanam mampu mengendalikan jamur Fusarium serta memacu perkecambahan benih dan pertumbuhan vegetatif tanaman (Sudantha, 2008).

c. Perlakuan dengan tanpa perendaman, yaitu benih di lumuri dengan dengan biakan Trichoderma koningii sesuai dosis 
perlakuan sesaat sebelum benih di tanam. Menurut Sofiana dkk (2018) dengan pelumuran biakan jamur Trichoderma viride pada benih kopi dengan dosis $200 \mathrm{~g}$ ternyata memiliki waktu perkecambahan lebih cepat dibandingkan dengan dosis lainnya. Nilai daya kecambah benih tertinggi sebesar 80,28\%. Sejalan dengan hasil penelitian Wijayanti dan Rahmawat (2017) pada benih Oyong yang di rendam menggunakan larutan Trichoderma spp. selama 2 hari tanpa disimpan memiliki Kecepatan Tumbuh diatas 17\%/ etmal, yaitu 17,65\%/ etmal, dengan Indeks Dormansi paling rendah yaitu $13,33 \%$.

3. Persiapan media tanam

Berupa pasir halus yang sudah ayak lalu di sterilakkan dengan cara di sangrai sekitar 10 menit, lalu masukan ke dalam polybag berukuran $25 \times 16 \mathrm{~cm}$, sebelum penanaman media di siram dengan air mineral sampai lembab.

4. Pelaksanaan perlakuan

a. Perlakuan pelumuran (Tanpa rendam) di lakukan sesaat sebelum tanam

1. $\mathrm{T} 50=$ benih di lumuri dengan dosis Trichoderma Koningii, sebanyak 50g/40 benih

2. $\mathrm{T} 100=$ benih di lumuri dengan dosis Trichoderma Koningii, sebanyak 100g/40 benih.

3. $\mathrm{T} 150=$ benih di lumuri dengan dosis Trichoderma Koningii, sebanyak 150g/40 benih.

4. $\mathrm{T} 200=$ benih di lumuri dengan dosis Trichoderma Koningii, sebanyak 200g/40 benih.

b. Perlakuan perendaman dengan suspensi Trichoderma koningii:

1. R6 jam = Trichoderma koningii di larutkan dengan air mineral sesuai dengan dosis perlakuan （yaitu: $50 \mathrm{~g}, 100 \mathrm{~g}, 150 \mathrm{~g}, 200 \mathrm{~g}$,/ liter/40 benih) di kocok lalu benih di masukan, di rendam selama 6 jam.

2. $\mathrm{R} 12 \mathrm{jam}=$ Trichoderma koningii di larutkan dengan air mineral sesuai dengan dosis perlakuan (yaitu: $50 \mathrm{~g}, 100 \mathrm{~g}, 150 \mathrm{~g}, 200 \mathrm{~g}$,/ liter/40 benih) di kocok lalu benih di masukan, di rendam selama 12 jam.

3. $\mathrm{R} 18 \mathrm{jam}=$ Trichoderma koningii di larutkan dengan air mineral sesuai dengan dosis perlakuan (yaitu: $50 \mathrm{~g}, 100 \mathrm{~g}, 150 \mathrm{~g}, 200 \mathrm{~g}$, / liter/40 benih) di kocok lalu benih di masukan di rendam selama 18 jam. c. Perlakuan perendaman tanpa dosis Trichoderma koningii :

1. R6 = Benih di masukan kedalam air minreal kemudian di rendam selama 6 jam

2. $\mathrm{R} 12=$ Benih di masukan kedalam air minreal kemudian di rendam selama 12 jam

3. $\mathrm{R} 18=$ Benih di masukan kedalam air minreal kemudian di rendam selama 18 jam

5. Penanaman Benih

Benih di semai kedalam media tanam sedalam $2 \mathrm{~cm}$ lalu di tutup kembali dengan pasir, di tempatkan di tempat terlindung.

\section{Variabel Pengamatan}

\section{Daya Berkecambah (DB).}

Daya berkecambah adalah kemampuan benih untuk tumbuh dan berkembang menjadi kecambah normal (ISTA, 2010)

Keterangan :

$$
\mathrm{DB}(\%)=\Sigma \mathrm{KN} / \mathrm{JB} \times 100 \%
$$

$\mathrm{DB}=$ daya berkecambah

$\mathrm{KN}=$ kecambah normal

$\mathrm{JB}=$ jumlah benih yang dikecambahkan

\section{Kecepatan Berkecambah (KB)}

Diamati setiap hari sehingga hari terakhir pengamatan terhadap kecambah normal, Dengan rumus sebagai berikut (Sutopo, 2004) :

$$
\mathrm{KB}=\frac{\mathrm{n} 1 \mathrm{~h} 1+\mathrm{n} 2 \mathrm{~h} 2+\mathrm{n} 3 \mathrm{~h} 3+\ldots . . \mathrm{nihi}}{\mathrm{n} 1+\mathrm{n} 2+\mathrm{n} 3+\quad \ldots . . \mathrm{ni}}=\frac{\sum \mathrm{nihi}}{\sum \mathrm{ni}}
$$

Keterangan :

$\mathrm{Ni}=$ Jumlah benih yang kecambah pada hari ke-i (butir)

$\mathrm{Hi}=$ Jumlah hari yang diperlukan untuk mencapai jumlah kecambah ke-ni

3. Indeks Vigor Benih

Indeks vigor dihitung dengan menghitung hari yang diperlukan untuk berkecambah dengan banyaknya jumlah benih yang berkecambah. Menurut Sutopo (2012) indeks vigor dihitung dengan menggunakan rumus dibawah ini :

$$
\mathrm{IV}=\frac{\mathrm{G} 1}{\mathrm{D} 1}+\frac{\mathrm{G} 2}{\mathrm{D} 2}+\frac{\mathrm{G} 3}{\mathrm{D} 3} \cdots \frac{\mathrm{GN}}{\mathrm{DN}}
$$

Keterangan :

$\mathrm{IV}=$ Indeks Vigor

$\mathrm{G}=$ Jumlah benih yang berkecambah pada hari tertentu

$\mathrm{D}$ = Waktu yang bersesuaian dengan jumlah tersebut

$\mathrm{N}=$ Jumlah hari pada perhitungan terakhir 


\section{Analisis Data}

Untuk mengetahui pengaruh perlakuan dari masing-masing perlakuan terhadap variabel maka dilakukan analisis statistik dengan uji $\mathrm{F}$, apabila uji $\mathrm{F}$ dari masing-masing perlakuan maupun interaksinya menunjukan beda nyata maka dilanjutkan dengan uji $\mathrm{Bnt}=0,05$.

\section{HASIL DAN PEMBAHASAN}

\section{Daya Berkecambah (DB)}

Dari hasil analisis sidik ragam interaksi Trichoderma koningii dan lama perendaman berpengaruh nyata terhadap daya kecambah benih sirsak, serta faktor tunggal dosis Trichoderma koningii berpengaruh sangat nyata terhadap daya kecambah benih sirsak. Nilai rata-rata daya kecambah benih sirsak dengan perlakuan Trichoderma koningii, lama perendam dapat di lihat pada Tabel 2.

Tabel 2. Nilai rata-rata daya kecambah (\%) benih sirsak dengan perlakuan Trichoderma Koningii dan lama perendaman.

\begin{tabular}{lllll}
\hline \multicolumn{3}{c}{$\begin{array}{l}\text { Dosis Trichoderma } \\
\text { koningii (Gram) }\end{array}$} & \multicolumn{4}{c}{ Lama } & \multicolumn{3}{c}{ Perendaman (Jam) } \\
\cline { 2 - 5 } R0 & \multicolumn{2}{c}{ R6 } & R12 & R18 \\
\hline T0 & $23,33^{\text {ef }}$ & $16,67^{\text {d }}$ & $16,67^{\text {d }}$ & $53,33^{\text {bcd }}$ \\
T50 & $26,67^{\text {edf }}$ & $23,33^{\text {ef }}$ & $66,67^{\text {ab }}$ & $43,33^{\text {bcdef }}$ \\
T100 & $50,00^{\text {bcde }}$ & $36,67^{\text {cdef }}$ & $46,67^{\text {bcde }}$ & $33,33^{\text {bcd }}$ \\
T150 & $46,67^{\text {bcde }}$ & $56,67^{\text {bc }}$ & $36,67^{\text {edf }}$ & $56,67^{\text {bc }}$ \\
T200 & $86,67^{\text {a }}$ & $36,67^{\text {cdef }}$ & $63,33^{\text {abc }}$ & $50,00^{\text {bcde }}$ \\
\hline Uji Bnt 5\% = 29,975 & & &
\end{tabular}
Keterangan : Rata-rata yang di ikuti dengan huruf yang sama tidak
beda nyata pada taraf uji Bnt $5 \%$.

Tabel 2 menunjukkan bahwa perlakuan dosis Trichoderma koningii tanpa rendam dosis 200g dapat meningkatkan daya kecambah benih sirsak sebesar $86,67 \%$, berbeda tidak nyata dengan dosis 50g pada lama perendaman 12 jam (T50R12) dan dosis 200g pada lama perendaman 12 jam 200g (T200R12). Perlakuan dosis tanpa Trichoderma koningii pada lama perendaman 18 jam (T0R18) meningkatkan daya kecambah sebesar $53,33 \%$, berbeda nyata dengan dosis tanpa Trichoderma koningii pada lama perendaman 6 dan 12 jam, namun berbeda tidak nyata dengan semua dosis Trichoderma koningii pada lama perendaman 18 jam, juga dengan dosis 50g pada lama perendaman 12 jam (T50R18), dosis $100 \mathrm{~g}$ pada lama perendaman 12 jam (T100R12), dosis 200g pada lama perendman 18 jam (T200R18), dan dosis $150 \mathrm{~g}$ pada lama perendaman 6 jam (T150R6).
Pada perlakuan dosis Trichoderma koningii tanpa terendaman (R0) merupakan model yang terbaik di mana nilai daya kecambah tertinggi $86,67 \%$, dengan nilai tersebut memenuhi standar kwalitas benih bermutu tinggi. Daya berkecambah minimum yaitu $80 \%$ untuk standar kualitas benih bermutu tinggi. Daya kecambah secara umum memenuhi standar mutu benih international seed testing association (ISTA) minimal tumbuh > $80 \%$. Daya kecambah benih memberikan informasi kepada pemakai benih akan kemampuan benih tumbuh normal menjadi tanaman yang berproduksi wajar dalam keadaan biofisik lapangan yang serba optimum (Sutopo, 2004).

Hasil penelitian ini sejalan dengan hasil penelitian Martinius dkk (2017) menyatakan bahwa perlakuan benih cabai dengan isolat Trichoderma endofit dapat meningkatkan daya kecambah normal benih cabai 4,1l-68,28\%, persentase bibit muncul lapang 31,90-41,43\%. Menurut Andayaningsih (2002) menyatakan bahwa pemberian Trichoderma spp meningkatkan persentase perkecambahan benih kedelai. Hasil penelitian Doni et al (2014) melaporkan bahwa persentase pengecambahan yang tinggi pada benih padi yang diberi perlakuan Trichoderma spp. berkisar 96 hingga 99\% dibandingkan kontrol. Pandey et al (2017) menyatakan bahwa Trichoderma harzianum dan Trichoderma koningii efektif untuk meningkatkan perkecambahan dan pertumbuhan tanaman baik secara tunggal atau dalam kombinasi dengan Arbuscular mycorrhiza (AM) bahkan dengan adanya patogen.

\section{Kecepatan Berkecambah (KB)}

Hasil analisis sidik ragam perlakuan dosis Trichoderma koningii, lama perendaman, dan interaksinya berpengaruh tidak nyata terhadap kecepatan kecambah benih sirsak. Nilai rata-rata kecepatan kecambah benih sirsak dengan perlakuan Trichoderma koningii, lama perendaman dan dapat dilihat pada Tabel 3 .

Tabel 3. Nilai rata-rata kecepatan kecambah (hari) benih sirsak umur 60 hari dengan perlakuan dosis Trichoderma koningii dan lama perendaman.

\begin{tabular}{lcccc}
\hline \multirow{2}{*}{$\begin{array}{c}\text { Dosis } \\
\text { Trichoderma } \\
\text { koningii } \text { (gram) }\end{array}$} & R0 & R6 & R12 & R18 \\
\cline { 2 - 5 } T0 & 39,00 & 32,33 & 45,17 & 49,01 \\
T50 & 43,61 & 32,61 & 30,13 & 28,27 \\
T100 & 46,28 & 35,87 & 32,18 & 33,83 \\
T150 & 32,56 & 40,35 & 35,13 & 25,90 \\
T200 & 27,47 & 45,78 & 24,07 & 29,31 \\
\hline Uji Bnt 5\% = 18,259 & & \\
\hline Keterangan : Rata-rata yang di ikuti dengan huruf yang sama tidak \\
\multicolumn{4}{c}{ beda nyata pada taraf uji Bnt 5\%. }
\end{tabular}


Tabel 3 menunjukkan bahwa perlakuan dosis tanpa Trichoderma koningii pada lama perendaman 18 jam memberikan kecepatan kecambah terlama sebesar 49,013 hari, namun berbeda tidak nyata dengan dosis $200 \mathrm{~g}, 150 \mathrm{~g}$, $100 \mathrm{~g}, 50 \mathrm{~g}$ pada lama perendaman 6 jam dan dosis $100 \mathrm{~g}$ dan $150 \mathrm{~g}$ pada lama perendaman $12 \mathrm{jam}$, maupun dosis $100 \mathrm{~g}$ pada lama perendaman $18 \mathrm{jam}$ (T100R18). Perlakuan dosis Trichoderma koningii tanpa rendam pada dosis 100g (T100R0) memberikan kecapatan kecambah sebesar 46,280 hari namun berbeda tidak nyata dengan semua dosis Trichoderma koningii pada lama perendaman 6 jam, dosis $100 \mathrm{~g}$ dan $150 \mathrm{~g}$ pada lama perendaman 12 jam, serta $100 \mathrm{~g}$ pada lama perendaman 18 jam.

Perlakuan dengan dosis 200g pada lama perendaman 12 jam dengan nilai kecepatan terendah 24,070 hari merupakan perlakuan yang terbaik dengan kecepatan kecambah yang tercepat walaupun berbeda tidak nyata dengan dosis $150 \mathrm{~g}$ pada lama perendaman 18 jam (T150R18) maupun dengan dosis $200 \mathrm{~g}$ tanpa perendaman (T200R0).

Hasil analisis tidak ada interaksi antara dosis Trichoderma koningii dan lama perendaman terhadap kecepatan kecambah benih sirsak hal ini di sebabkan karena kulit benih sirsak yang tebal dan keras sehingga pelumuran dan lama perendaman dengan suspensi Trichoderma koningii belum dapat melunakan kulit benih sirsak yang impermeable terhadap air dan udara atau mungkin dosis Trichoderma koningii yang masih rendah dan lama perendaman yang masih singkat sehingga fithohormon yang ada pada Trichoderma koningii belum mampu melunakan kulit benih sirsak sehingga belum dapat mempercepat perkecambahan. Kulit benih keras pada umumnya menghambat perkecambahan walaupun disemaikan pada kondisi perkecambahan yang optimum Titin dkk (2018). Kulit benih keras pada umumnya menghambat perkecambahan walaupun disemaikan pada kondisi perkecambahan yang optimum Titin dkk (2018).

\section{Indeks Vigor}

Hasil analisis sidik ragam perlakuan Trichoderma koningii, lama perendaman maupun interaksinya. Perlakuan Trichoderma koningii sangat nyata terhadap vigor benih sirsak dan interaksi Trichoderma koningii dan lama perendaman pengaruh nyata terhadap vigor benih sirsak. Nilai rata-rata indeks vigor benih sirsak dengan perlakuan Trichoderma koningii dan lama perendaman dapat di lihat pada Tabel 4.

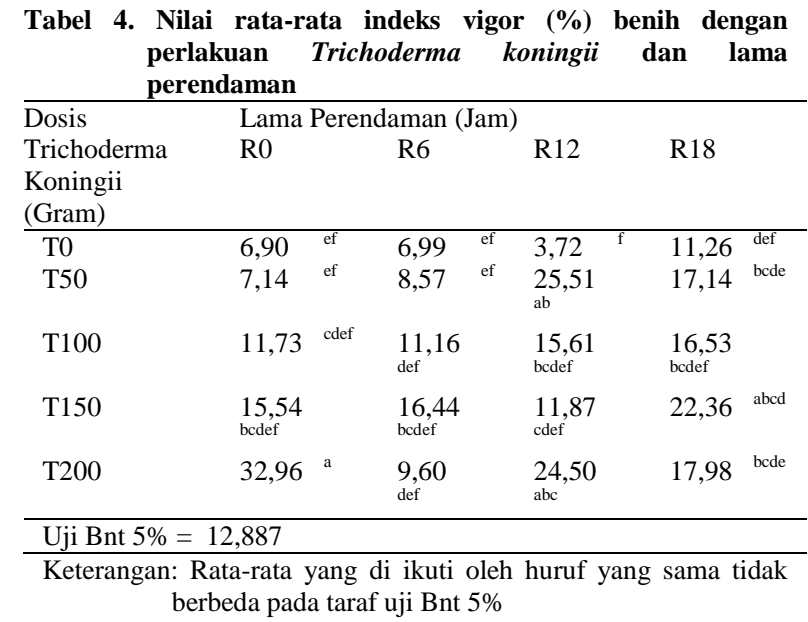

Tabel 4 menunjukkan bahwa perlakuan dosis Trichoderma koningii tanpa rendam 200g (T200R0) memberikan nilai indeks vigor tertinggi sebesar 32,964\% berbeda tidak nyata dengan dosis dosis $200 \mathrm{~g}$ pada lama perendaman 12 jam (T200R12), juga dosis 50g pada lama perendaman 12 jam (T50R12), dosis 150g pada lama perendaman 18 jam (T150R18), berbeda nyata dengan semua dosis Trichoderma koningii pada lama perendaman 6 jam. Perlakuan dosis tanpa Trichoderma koningii pada lama perendaman 18 jam (T0R18) memberikan indeks vigor tertinggi 11,263 berbeda tidak nyata dengan dosis $100 \mathrm{~g}$ pada lama perendaman 6 jam, juga dosis $150 \mathrm{~g}$ pada lama perendaman 18 jam (T150R18), maupun dengan dosis Trichoderma koningii 100g tanpa perendaman (T100R0). Perlakuan dosis tanpa Trichoderma koningii pada lama perendaman 12 jam (T0R12) dengan indeks vigor terendah $3,719 \%$ namun berbeda tidak nyata dengan dosis tanpa Trichoderma koningii pada lama perendaman 6 jam (T0R6), juga dengan dosis 50g tanpa perendaman (T50R0) maupun dengan kontrol.

Dari hasil analisis ada interaksi antara dosis Trichoderma koningii dan lama perendaman terhadap indeks vigor benih, pada dosis Trichoderma koningii 200g tanpa rendam (T200R0) memberikan nilai indeks vigor tertinggi di banding dengan perlakuan lainnya, tingginya nilai indeks vigor selaras dengan tingginya daya kecambah benih sirsak. Vigor benih tinggi memiliki kekuatan tumbuh dan potensi tumbuh di lapang yang tinggi. Sejalan dengan hasil penelitian Menurut hasil penelitian Jegathambigai et al (2009) Perlakuan benih dengan Trichoderma meningkatkan perkecambahan sebesar 24,03\%, indeks vigor bibit sebesar $23,29 \%$ dan 
mengurangi insiden bercak daun. Menurut Doni et al (2014) menyatakan bahwa rata- rata indeks vigor benih padi dengan perlakukan Trichoderma spp. berkisar dari 655,73 menjadi 1016,56 dibandingkan dengan kontrol. Indeks vigor millet meningkat dengan aplikasi jamur Trichoderma viride hingga konsentrasi $50 \%$ dan kemudian menurun dengan konsentrasi $75 \%$ kurang dari kontrol (Hassan et al, 2014)

Kumar et al (2014) melaporkan perlakuan Trichoderma harzianum dan Trichoderma viride pada kacang buncis dengan konsentrasi 5\% meningkatkan persentase perkecambahan $90 \%$, panjang akar $12,19 \mathrm{~cm}$, tinggi bibit 16,50 $\mathrm{cm}$, berat kering $1,88 \mathrm{~g}$ dan indeks vigor 1485,00. Zheng dan Shetty (2000) melaporkan bahwa Trichoderma spp. menginduksi produksi senyawa fenolik selama perkecambahan biji, senyawa fenolik ini yang menyebabkan peningkatan indeks vigor benih.

\section{KESIMPULAN DAN SARAN}

\section{Kesimpulan}

Berdasarkan hasil penelitian maka dapat di ambil kesimpulan sebagai berikut:

1. Dosis Trichoderma koninggi $200 \mathrm{~g}$ tanpa rendam mampu meningkatkan daya kecambah sebesar 86,67\% dan indeks vigor sebesar 32,964\%.

2. Perendaman dengan suspesi Trichoderma koninggi belum dapat menginduksi kecepatan perkecambahan benih sirsak.

3. Interaksi antara dosis Trichoderma koningii dan lama perendaman berpengaruh terhadap, panjang plumula, berat kering oven radikula, berat kering oven plumula, indeks vigor dan kadar klorofil daun benih sirsak, namun tidak berpengaruh terhadap kecepatan perkecambahan benih sirsak.

\section{Saran}

Dosis Trichoderma koningii dan perendama dengan suspensi Trichoderma koningii belum mampu menginduksi kecepatan kecambah benih sirsak, dosis dan durasi perendaman mungkin perluh di tingkatkan untuk memacuh percepatan perkecambahan benih sirsak.

\section{DAFTAR PUSTAKA}

Ali, A., Haider, M. S. Ashfaq, M. and S. Hanif. 2014. Effect Of Culture Filtrates Of Trichoderma Spp. On Seed Germination And Seedling Growth In Chickpea - An In-Vitro Study. Pakistan Journal of Phytopathology.

Andayaningsih. P. 2002. Kemampuan Trichoderma Spp. Dalam Pengendalian Patogenitas Rhizoctonia Solani Pada Tanaman Kedelai. F-MIPA Universitas Padjadjaran. Jatinangor, Bandung 40600. Jurnal ilmu-lmu hayati dan fisik.

Asaduzzaman, M., M. J. Alam. And M. M. Islam. 2010. Effect Of Trichoderma On Seed Germination And Seedling Parameters Of Chili.http://citeseerx.ist.psu.edu/viewdoc/dow nload?doi=10.1.1.895.2303\&rep=rep1\&type= pdf.

Badrie, N. and A. G. Schauss. 2009. Soursop (Annona muricata L.) : Composition, Nutritional Value, Medicinal Uses and Toxicology. In : R.R. Watson and V. R. Preedy (eds.). Bioactive Foods in Promoting Health. Academic Press, Oxford. p. 621-643/.

Cai, F. G., P. Yu., Z. Wang., L. Wei., Q. Fu., Shen and W. Chen. 2013. Harzianolide, a novel plant growth regulator and systemic resistance elicitor from Trichoderma harzianum. Plant Physiol. Bioch., 73: 106113.

Delgado- Sanchez, P., M. A. Ortega.- Amora., A. A. Rodríguez- Hernández., J.F. JiménezBremon and J. Flores. 2010. Further evidence from the effect of fungi on breaking Opuntia seed dormancy. División de Ciencias Ambientales; 2División de Biología Molecular; Instituto Potosino de Investigación Científica y Tecnológica; San Luis Potosi, Mexico.

Doni, F., I. Anizan., C. M. Z. C. Radziah., A.H., Salman., M.H., Rodzihan and W.M. W. Yusoff. 2014. Enhancement of Rice Seed Germination and Vigour by Trichoderma spp. School of Biosciences and Biotechnology, 2 Department of Geology, School of Environmental and Natural Resources Sciences, Faculty of Science and Technology, University Kebangsaan Malaysia, 43600 Bangi, Selangor, Malaysia. 
Harman, G. E. 2000. Overview of mechanisms and uses of Trichoderma spp. Phytopathology, 96: 190-194.

Harman, G. E. Howell, C. R. Viterbo, A. Chet, I. M. Lorito. 2004. Trichoderma SpeciesOpportunistic, Avirulent Plant Symbionts. Nature Reviews In Microbiology 2: 4356. https://doi. org/10.1038/nrmicro797.

International Seed Testing Association (ISTA). 2007. International Rules for Seed Testing. Bassedorf. Switzerland.

Jegathambigai,V. R.S. W. Wijeratnam and R.L.C Wijesundera. 2009. Trichoderma as a Seed Treatment to Control Helminthosporium Leaf Spot Disease of Chrysalidocarpus lutescens. Green Farms Ltd., Marawila, Sri Lanka. Industrial Technology Institute, 363, Bauddhaloka Mawatha, Colombo 07, Sri Lanka. Department of Plant Sciences, University of Colombo, Sri Lanka. World Journal of Agricultural Sciences 5 (6): 720728, 2009 ISSN 1817-3047 (C) IDOSI Publications, 2009 Corresponding Author: V. Jegathambigai, Green Farms Ltd., Marawila, Sri Lanka 720.

Kaveh, H., S. V. Jartoodeh., H. Aruee and M. Mazhabi. 2011. Would Trichoderma Affect Seed Germination and Seedling Quality of Two Muskmelon Cultivars, Khatooni and Qasri and Increase Their Transplanting Success?. Department of Horticulture, Ferdowsi university of Mashhad, Azadi square, Mashhad, Iran. J. Biol. Environ. Sci., 2011, 5(15), 169-175.

Kumar, A., A. Patel., S. N. Singh And R. K. Tiwari. 2014. Effect Of Trichoderma Spp. In Plant Growth Promotion In Chilli. Jawaharlal Nehru Krishi Vishwa Vidyalaya (JNKVV) College of Agriculture, Jabalpur, M.P. 482 O0.Jawaharlal Nehru Krishi Vishwa Vidyalaya (JNKVV) College of Agriculture, Rewa, M.P. 486001. International Journal of Current Microbiology and Applied Sciences ISSN: 2319-7706 Volume 8 Number 03 (2019).
Lalitha, P., Srujana and K. Arunalakshmi. 2012. Effect of Trichoderma viride on germination of mustard and survival of mustard seedlings. Int. J. Life Sci. Biotechnol. Pharma Res., 1(1).

Martinius., Darnetty., Trizelia., Dan S. Herdina. 2017. Kemampuan Trichoderma Endofit Dalam mengendalikan Jamur Patogen Tular Beni Cabai. Fakultas Pertanian, Universitas Andalas. hal.18.

Mukherjee, P. K., B. A. Horwitz., U. S Singh., M. Mukherjee and M. Schmoll. 2013. Trichoderma in agriculture, industry and medicine : an overview. In: Trichoderma: biology and applications. Mukherjee PK, Horwitz BA, Singh US, Mukherjee M, Schmoll M (Eds.). CABI, Nosworthy, Way, Wallingford, Oxon, UK, pp. 1-9.

Okoth, S. A., J. A. Otadoh and J. O. Ochanda. 2011. Improved seedling emergence and growth of maize and beans by Trichoderma harziunum. Trop. Subtrop. Agroecosyst., 13: 65-71. Pandey. M. 2017. Effect of Trichoderma species on germination and root disease control in neem seedlings. The Pharma Innovation Journal 2017; 6(11): 757761.

Sudantha, I. M. 2008. Aplikasi Jamur Trichoderma spp. (Isolat ENDO-02 dan 04 serta SAPRO07 dan 09) sebagai Biofungisida, Dekomposer dan Bioaktivator Pertumbuhan dan Pembungaan Tanaman Vanili dan Pengembangannya pada Tanaman Hortikultura dan Pangan Lainnya di NTB. Laporan Penelitian Hibah Kompetensi DP2M -Fakultas Pertanian Universitas Mataram, Mataram. 117 hal.

Sutopo, L. 2004. Teknologi Benih, Jakarta. Divisi Buku Perguruan Tinggi PT Raja Grafindo Persada.

Titin, Y. Tambing dan Ramli. 2018. Induksi Perkecambahan Benih Sirsak (Annona Muricata L.) Dengan Perlakuan Skarifikasi Dan $\mathrm{KNO}_{3}$. Mahasiswa Program Studi Agroteknologi Fakultas Pertanian Universitas Tadulako, Palu .Email : Thitin.tamuse@gmail.com. Staf Dosen Program Studi Agroteknologi Fakultas Pertanian Universitas Tadulako, Palu. 
Wijayanti, R. dan D. Rahmawati. 2017. Aplikasi Trichoderma Sp. Dan Lama Penyimpanan Terhadap Dormansi Benih Oyong (Luffa Acutangula (L.) Roxb.). Program Studi Teknik Produksi Benih Departemen Produksi Pertanian, Politeknik Negeri Jember.

Windham, M. T., Y. Elao and R.A. Baker. 1986. Mechanisme for increased plant growth induced by Trichodermaspp. Phytopathology. 76:518-521.
Wirawan, G. S. 2018. Pengaruh Trichoderma Sp. Sebagai Agen Peningkatan Ketahanan Tanaman Padi Terhadappenyakit Hawar Daun Bakteri. Fakultas Pertanian Universitas Lampung Bandar Lampung.Skripsi.

Zheng, $\mathrm{Z}$ and K. Shetty. 2000. Enhancement Of Pea (Pisum Sativum) Seedling Vigour And Associated Phenolic Content By Extracts Of Apple Pomace Fermented With Trichoderma Spp. Process Biochem.,36 : 79-84. 